\title{
Stress Tests By The European Banking Authority: The Immunity Of Italian Cooperative Banks
}

Andrea Quintiliani, Pegaso Telematic University, Italy

\begin{abstract}
Purpose. The objectives of the paper are two-fold. The first objective of the research is formulated with the intent to analyze the existence or not of a possible "European Banking Authority (EBA) effect" on the credit offer of local banks compared with national banks subject to the requests of capital from European Authority. The second research objective aims to understand what are the conditions that allow to develop a model of a local bank capable of supporting SMEs, with a suitable risk-return profile.
\end{abstract}

Methodology. This paper presents an empirical comparative analysis between Cooperative Credit Banks (BCCs) and Italian banking groups.

Findings. The empirical analysis shows how the financial then real crisis has not induced BCCs to restrict credit to firms. In particular, the BCCs not included in stress exercises, show, unlike national banks, a substantial "independence" of credit trend from the advices of the Authority. The survey evidences have however highlighted some critical elements that are reflected inevitably on the local bank's risk-return profile.

Research Limitations. The quantitative nature of the empirical analysis must be followed by a qualitative analysis in order to strengthen the validity of the results.

Implications. This work will be useful to stimulate the debate on the studies of local banks and their anti-cyclic role in favor of the SMEs.

Originality. The work affects an aspect which has hitherto been little studied.

Keywords: Local Bank; Lending; SME; Financial Crisis; EBA; Stress Exercise

\section{INTRODUCTION}

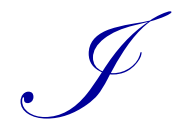
n Europe, capital requirements directive comes from both the new regulations of Basel 3 and EBA recommendations (European Banking Authority), following to the stress test recently carried out. However, during economic recession periods this directive can stimulate vicious circles owing to credit rationing effects. The aim of this work is to analyze the existence or not of a probable "EBA effect" regarding the credit offer of local banks, notoriously oriented to manage the credit-risk by "relationship lending" approach, compared with medium-large national banks (or banking groups), notoriously "transaction lending" and subject to the capitalisation requests of European Authority. More precisely, the research is carried out upon the formulation of two research questions: about the credit dynamics of the five major Italian banks (s.c. national) subject to the EBA stress exercises and on the contrary the latter about the credit dynamics of Cooperative Credit Banks (s.c. locals) on the home territory and not included, for their nature, among stress exercises (R.Q.1); the second research target intends to understand what are the conditions that allow to develop a model of a local bank capable of supporting the development routes of SMEs, by an appropriate risk-return profile (R.Q.2). 
On the basis of the two research questions, methodologically the research structure develops as follows.

The second paragraph proposes a literature study about credit rationing; besides, it offers a review of the main theoretical contributions about the local banks and the relationship banking as a relational approach to clientele. The theme regarding the relationship between the local bank and the relational systems with clientele represents an introduction to the discussion with the purpose to catch the effects on the credit dynamics to enterprises.

In order to answer the first research questions (R.Q.1), the third paragraph shows an empirical compared analysis, for the period 2007-2012, concerning Italian Cooperative Credit Banks (BCCs) in comparison with the system of banking groups with operations spread on a large part of the Italian territory and not. On the whole, the empirical analysis is finalized to estimate the impact of capital requirements directive on banking lending policies.

The credit influenced by EBA recommendations is monitored by the aid of a set of ratios. In particular, the empirical analysis is carried out by examining three prevailing areas: credit trends, credit risk and capital strength.

In line with a previous study of Quintiliani (2017), the empirical analysis continues with the check of further goaloriented indicators monitoring the following profiles: structure, riskiness and efficiency. In order to answer the second research question (R.Q.2), the fourth paragraph gives some evolutionary reflection cues about business models of local banks.

\section{THE MAJOR DETERMINANTS OF CREDIT RATIONING}

In the context of Bank-Enterprise relationship, the phenomenon of credit rationing has been analysed through different perspective.

From a theoretical viewpoint, different schools of thought have taken back, during the years, the phenomenon to a series of causes; among the principal ones (Quintiliani, Modina \& Arnone, 2013): 1. Exogenous shocks to banks; 2. Endogenous shocks to banks; 3. Imperfect distributions of information (asymmetric information); 4. Bank-Firm distance; 5. The bank's size; 6. Nature of the Bank-Firm relationship.

With reference to the first aspect, negative exogenous shocks determine standstill phenomena, on economic system scale, and banking crises. Lendings shrink up to obtain phenomena of credit crunch (Bernanke \& Lown, 1991; Domaç \& Ferri, 1998).

With reference to the second aspect, the shocks inside banks lead to strong large erosion of banking assets with negative effects on the capability to issue loans (Allen, Carletti \& Gale, 2008).

Information asymmetries (the third point in the list) are produced owing to the opacity and poor disclosure of those who work in the credit market. Insufficient, full of gaps information can have repercussions on the general economy; in fact, due to the existence of a gap of knowledge between credit institutes and firms in need of funding, negative consequences can be generated in terms of rationing of financial resources for enterprises revealing valid business fundamentals, wrong pricing of loans, increasing of non-performing loans and non-optimal allocation of assets by banks in view of taken credit risks (Stiglitz \& Weiss, 1981).

Among the other doctrinal cues suitable to explain the credit rationing phenomenon, the studies concentrated on the distance Bank-Firm (the fourth point in the list) prove to be not marginal. The concept of distance is supported by the theme of banking localism. According to many authors, radicalization in a local community favours superior, economic performances in the tradictional activity of lending to families and firms, in particular, thanks to informational advantages (Fama, 1985; De Laurentis, 2011).

Strictly correlated to the concept of distance, the theme of size ( $5^{\text {th }}$ point in the list). Jayaratne and Wolken (1999) and Berger and Udell (2002) emphasize how small banks, prevalently oriented to the activity of credit intermediation (lending activities), hold relevant competitive advantages as regards the running of private information. Really, some research contributions highlight the role of small banks in the collection of soft information and the importance of 
their organizational structure in their use (Berger \& Udell, 2002; Berger, Miller, Petersen, Rajan \& Stein, 2005; Quintiliani, 2016).

Starting from the review about the themes of localism and size of the bank, this section is enriched by the examination of theoretical contributions about the theme regarding the nature of the Bank-Firm relationship (sixth item in list). In synthesis in literature two different relational models have emerged between banks and firms: the transaction lending approach and the relationship lending approach (Berger \& Udell, 2006). If the former approach is finalized to maximize the volume of intermediation produced by the bank through the standardization of offer and the use of the client's information being easily long-distance verifiable and standardized, the latter approach, more adopted by small, local banks, is finalized to realize net interest on a basis of solid, durable relations with the firm.

The literature on relationship lending has identified benefits and costs of this approach. According to Boot (2000) the exchange of reserved information between the bank and the firm can offer to firms to have a greater amount of credit, to create shareholder value and to better the firm performance. In particular, relationship lending makes easier the information exchange between a debtor and a creditor because debtors reveal to be more inclined to make known information to banks thanks to the greater discretion of relations (Yosha, 1995). Lesser information asymmetries allow to overcome the problems linked to moral hazard and adverse selection, otherwise inherent in credit markets (Diamond, 1991).

Relationship lending favours greater flexibility in the renegotiation of contract conditions (Boot, 2000; Rajan, 1992; Petersen \& Rajan, 1995).

The exclusivity of the relationship with the bank, implicit in the relationship lending, also creates the preconditions for the offer of an implicit insurance service (Berlin \& Mester, 1998; Ferri \& Messori, 2000). An extensive literature shows also how the relationship lending creates the preconditions for the improvement of the debtor's reputation (Fama, 1985; Diamond, 1991).

On the cost side, several authors show that the greatest risk of relationship lending is due to the hold-up problem, namely the capture of the business by the bank (Degryse \& Van Cayseele, 2000), creating the conditions for informational rents that result in the application of higher lending rates (Petersen \& Rajan, 1995; Corigliano, 2007).

\section{NATIONAL BANKS VS. LOCAL BANKS: EVIDENCE OF A POSSIBLE EFFECT EBA}

Coherently with the objectives of the paper, the surveyed banks are sampled in two known categories, respectively: "National Banks" and "Cooperative Credit Banks" (BCCs).

With reference to the former, the analysis examines the last six financial statements date (2007/2012 period) of a sample of five banking groups, considered among the dimensionally large ones based on the classification made by ABI, with widespread operations throughout the country (Intesa Sanpaolo, Unicredit, MPS; UBI, Banco Popolare), while the sample of local banks is made up of all the institutions operating in Italy (404) in the form of cooperative bank. The total sample has a good statistical significance since it covers $65 \%$ of the universe of active banks at the end of 2012 .

In relation to BCC (mutual bank), the audit was performed through the use of Federcasse database while the balancesheet data of the five banking groups were obtained through access to their institutional websites. In particular, the first sample is made up of five national banks considered big in the financial sector and submitted by the European Banking Authority (EBA) to a stress test in order to detect their capital solidity, while the second sample consists of 404 BCCs which, although not subject to EBA stress tests, are invited by the Bank of Italy to approach gradually to the new procedures leading to the awarding supplementary capital. In this regard, the President of Federcasse Alessandro Azzi, on the occasion of Federcasse 2015 meeting, highlighted how the new approaches to the capital base of banks (primarily the core tier 1) can outline the risks of systemic nature; among them: the risk of penalizing in terms of need for capital, especially the brokerage model suited to the real economy; the risk of myopia in recognizing the substantial differences between large banks of systemic importance and local intermediaries; the risk of erosion of bank capital (current or prospective) due to calculation methods that are the result of untested theoretical models. 
The shallow depth of the time series object of our investigation (2007-2012) has discouraged the use of econometric tools aimed at spotting the relationships between supplementary capital requirements and dynamics of bank credit; in fact, our research has focused solely on reading, processing and interpretation of annual financial statements (profit and loss and balance sheets).

The first sample is investigated, in aggregate, through three main drivers, declined on the basis of some significant variables: 1) Credit trends. The trend in lending was observed taking into account the Financial Activities (FA) and the Credits with Banks $(\mathrm{CrB})$ as well as the Credits with Costumers $(\mathrm{CrC})$. Aware that "national banks" have seen the IRBs models used since 2008 onwards, the trend of the aforesaid balance sheet items was related to 2007 (s.c. base year) also regarded as indicative of the beginning of the crisis; 2) Credit Risk. To assess, and understand better the dynamics that had an impact on the credit offered, Credit Write-Down were calculated; 3) Equity soundness. The capitalization was investigated by observing the dynamics of the Core Tier 1 ratio in the balance sheet as well as the dynamics of the ratio "Net Assets (NA) $\div$ Total Assets (TA)". The empirical analysis continues examining further ratios distributed for each profile as follows: Structure (Total collection $\div$ Total Assets, Due from customers $\div$ Direct deposits); Riskiness (Value adjustments on credit $\div$ Credits with customers); Profitability (Net interest income $\div$ Net interest and other banking and insurance income, Profit/Loss for the year $\div$ Net assets); Efficiency (Cost income ratio: Operating expenses $\div$ Net interest and other banking and insurance income).

In order to detect the existence or not of an "EBA" effect for local banks, the first sample of national banks was subject to comparison with the sample of local banks. Also in this case, the analysis has a descriptive nature, and focuses on the dynamics, at aggregate level, of the drivers mentioned above.

The comparative analysis of the two samples allows to verify and interpret the impact of "EBA recommendations" on drivers under investigation.

\subsection{Main Evidences of Banking Groups Sample}

The credit extended to bank's clients (Figure 1) shows a downward trend; after a leap in 2008, it records a drop that lasts until 2012.

Figure 1. The dynamics of credit to customers (period 2007-2012) - Banking groups sample (k€)

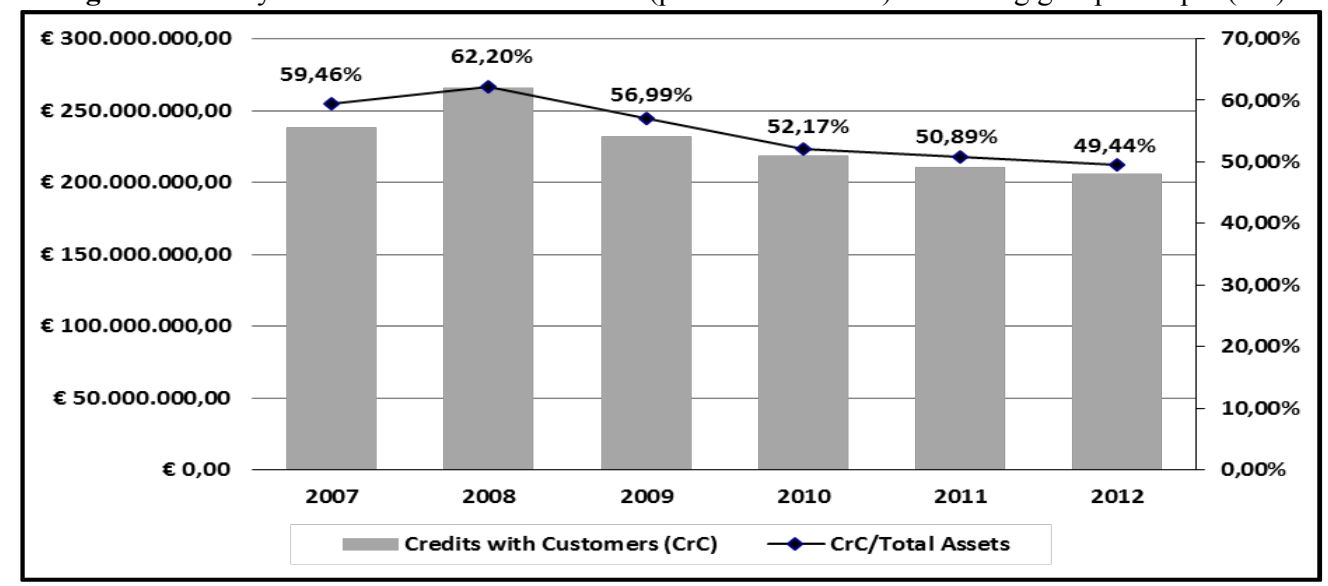

Source: Our elaboration on financial statements data.

The trend shows itself to be negative, both with reference to the first phase of the crisis (2008-2010) and in relation to the second period (2010-2012); in fact, this second period, subject of investigations, is characterized by EBA recommendations (stress tests conducted in 2010 and 2011) and the intensification of the sovereign of debt crisis. The results of stress tests in 2010 and 2011 reveal overall financial requirements (Excess Capital) of approximately $€ 15.4$ million. Continuing with the analysis of Figure 1, it is evident how the weight of credit to customers (as a percentage of the total assets - continuous line on the graph) registers a consistently negative trend; this phenomenon may be 
indicative of a deleverage process and banks repositioning. In December of 2011, four of the five sampled banks have deficits in the basic coefficient (Tier 1 ratio) (Figure 2).

Figure 2. Surplus/Deficit Core Tier 1 ratio - Banking groups sample

\begin{tabular}{|c|c|c|c|c|}
\hline \multirow[b]{2}{*}{ Bank } & \multicolumn{3}{|c|}{ Core Tier1 ratio July 2010} & \multirow{7}{*}{ Delta Effective } \\
\hline & Minimum required & Effective & Surplus/Deficit & \\
\hline INTESA SAN PAOLO & \multirow{5}{*}{ 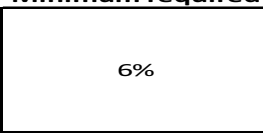 } & $8,03 \%$ & $2,03 \%$ & \\
\hline MPS & & $5,60 \%$ & $-0,40 \%$ & \\
\hline UBI & & $6,95 \%$ & $0,95 \%$ & \\
\hline \multirow{2}{*}{$\begin{array}{r}\text { BANCO POPOLARE } \\
\text { UNICREDIT }\end{array}$} & & $6,68 \%$ & $0,68 \%$ & \\
\hline & & $8,75 \%$ & $2,75 \%$ & \\
\hline & \multicolumn{3}{|c|}{ Core Tier1 ratio July 2011} & \\
\hline Bank & Minimum required & Effective & Surplus/Deficit & \\
\hline INTESA SAN PAOLO & \multirow{5}{*}{ 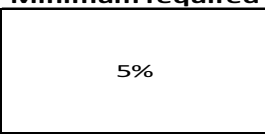 } & $10,24 \%$ & $5,24 \%$ & $27,49 \%$ \\
\hline MPS & & $8,65 \%$ & $3,65 \%$ & $54,34 \%$ \\
\hline UBI & & $8,72 \%$ & $3,72 \%$ & $25,48 \%$ \\
\hline \multirow{3}{*}{$\begin{array}{r}\text { BANCO POPOLARE } \\
\text { UNICREDIT }\end{array}$} & & $7,93 \%$ & $2,93 \%$ & $18,66 \%$ \\
\hline & & $8,61 \%$ & $3,61 \%$ & $-1,50 \%$ \\
\hline & \multicolumn{3}{|c|}{ Core Tier1 ratio December 2011} & \\
\hline Bank & \multirow[t]{6}{*}{ Minimum required } & Effective & Surplus/Deficit & \\
\hline INTESA SAN PAOLO & & $11,37 \%$ & $2,37 \%$ & $11,09 \%$ \\
\hline MPS & & $7,10 \%$ & $-1,90 \%$ & $-17,93 \%$ \\
\hline UBI & & $8,32 \%$ & $-0,68 \%$ & $-4,65 \%$ \\
\hline BANCO POPOLARE & & $8,58 \%$ & $-0,42 \%$ & $8,22 \%$ \\
\hline UNICREDIT & & $8,15 \%$ & $-0,85 \%$ & $-5,36 \%$ \\
\hline
\end{tabular}

Source: Our elaboration on financial statements data and EBA (2012).

In relation to the stated deficits and requests for additional capital buffers by EBA, the sampled banks have adjusted their capital by recording, in 2012, a Core Tier 1 average ratio in line with the European Authority requests (9.10 \%) - Figure 3.

Figure 3. Core Tier 1 ratio - Banking groups sample

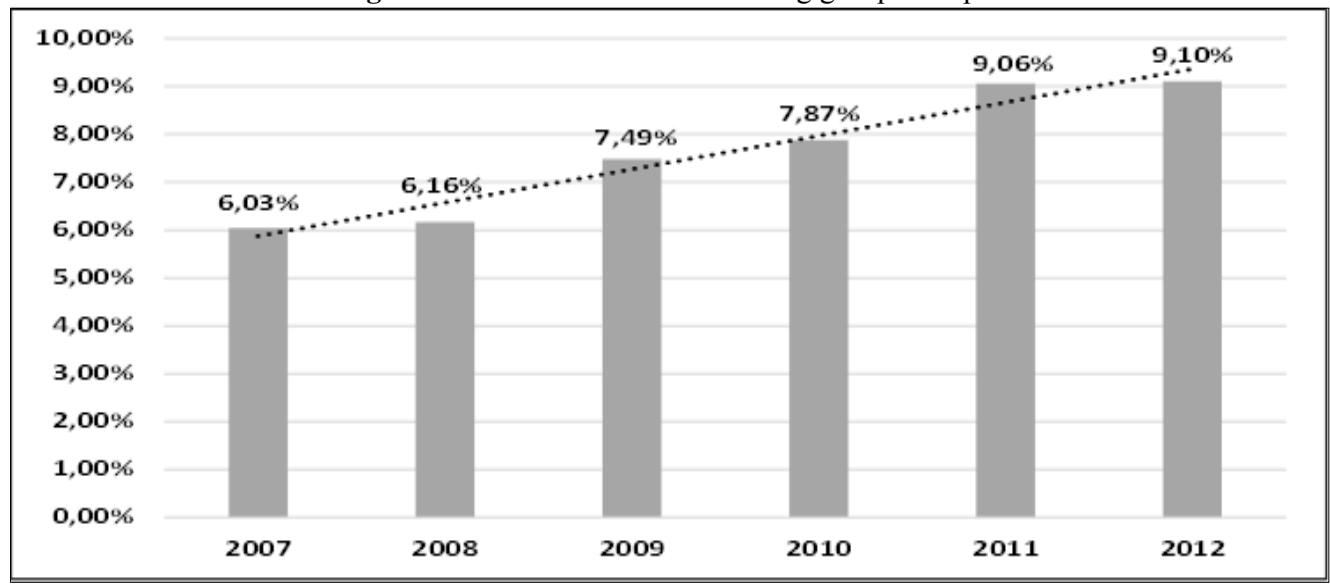

Source: Our elaboration on financial statements data and EBA (2012).

It is through the joint observation of the percentage changes compared to the base year 2007, Credit with customers $(\mathrm{CrC})$, Credit to customers \% Total Assets $(\mathrm{CrC} \div \mathrm{TA})$ and Financial Activities and Credit with Banks \% Total Assets $(\mathrm{AF} \& \mathrm{CrB} \div \mathrm{TA})$, that can be identified the factors that have influenced the operations of banks (Figure 4). 
Figure 4. Key items in the financial statements. Average rates of change (base year 2007) - Banking groups sample

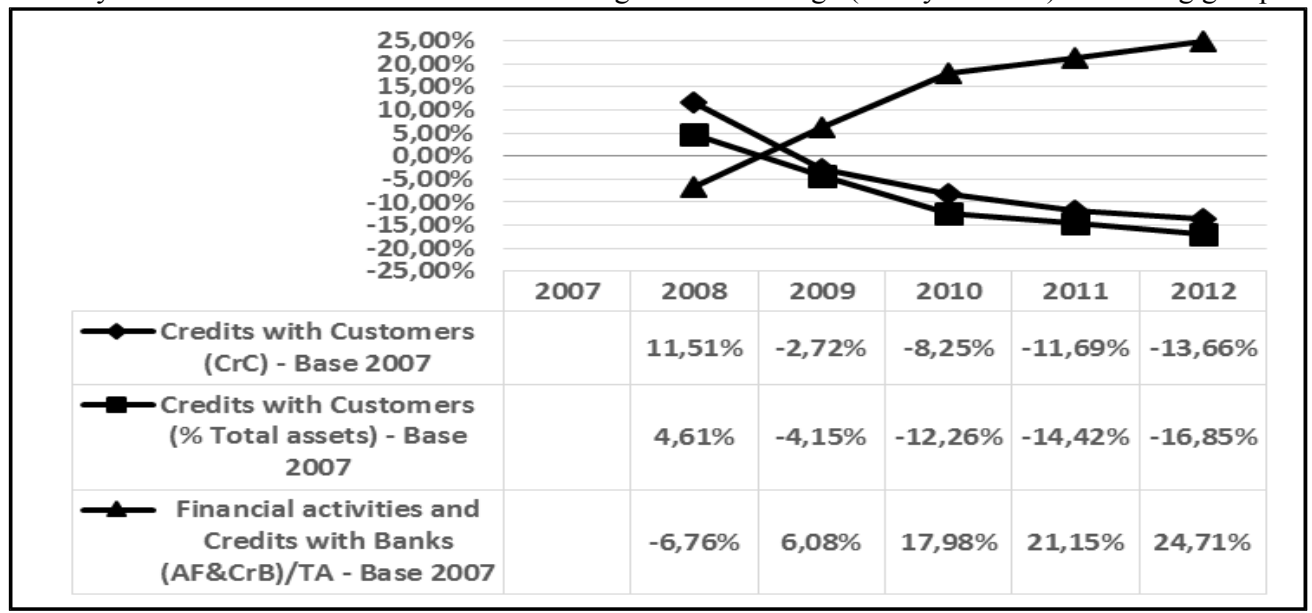

Source: Our elaboration financial statements data.

The year 2007, which corresponds with the entry into force of the New Basel Accord on Minimum Capital Requirements for Banks (Basel 2), saw banks take prudential attitudes in loan disbursement. The first and the second phase of the crisis (2008-2010, 2011-2012) have led banks to implement credit crunch policies in response to adverse economic events and progressive non-performing loans. These factors were accompanied by the EBA requests for supplementary capital; in fact, the national banks sampled had to comply with the new temporary capital buffer bringing Core Tier 1 from $6 \%$ to $9 \%$.

\subsection{Main Evidences Of Local Banks Sample}

Figure 5 shows the trend of $\mathrm{CrC}$ (histogram in Figure) for BCCs; these, included in the comparison sample, record an upward trend from 2007 until 2012. As we have already highlighted, the banks included in the comparison sample were not subject to stress tests but, in view of the system, these are also invited to follow the recommendations leading to the award of additional capital.

Figure 5. The dynamics of credit to customers (period 2007-2012) - Local banks sample (k€)

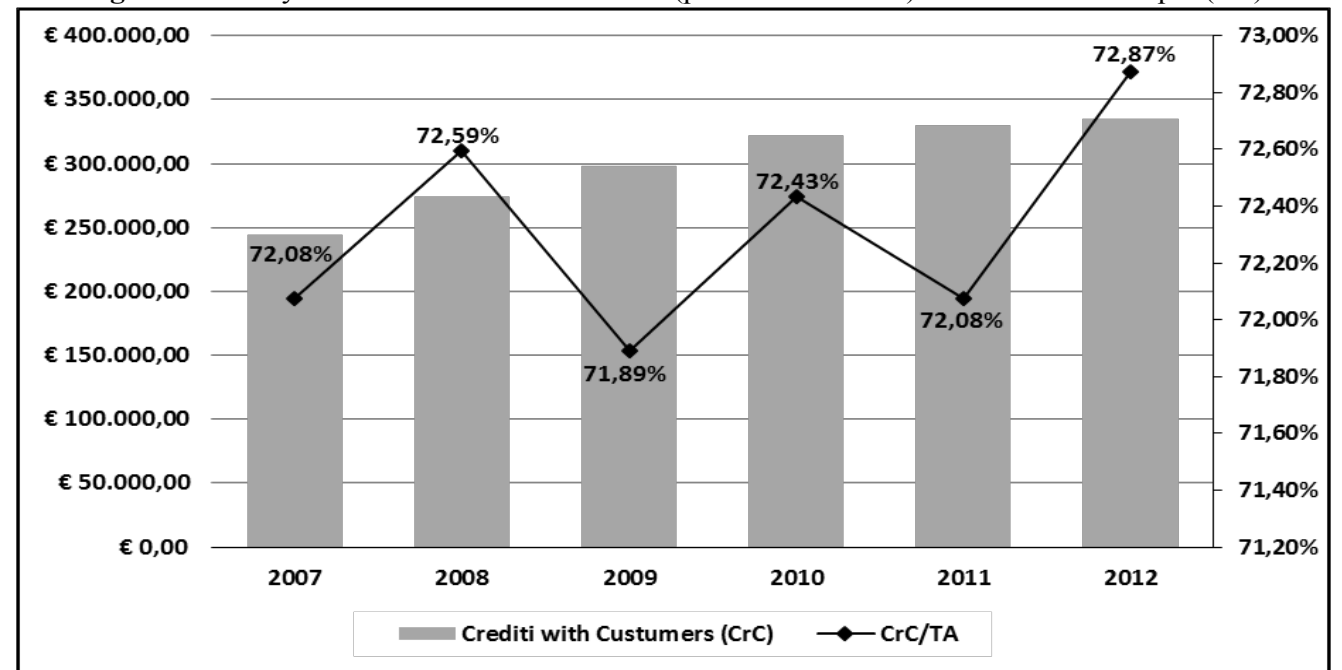

Source: Our elaboration on Federcasse data. 
As we can see from Figure 6, in the years when stress tests were carried out (2010-2012), BCCs recorded, unlike the sample of national banks, the gradual growing trend (compared with the 2007 base year) of $\mathrm{CrC}$. The asset composition ratios show, however, low percentage delta; this phenomenon is to be reconnected to the absence, compared with national banks, of deleverage phenomena.

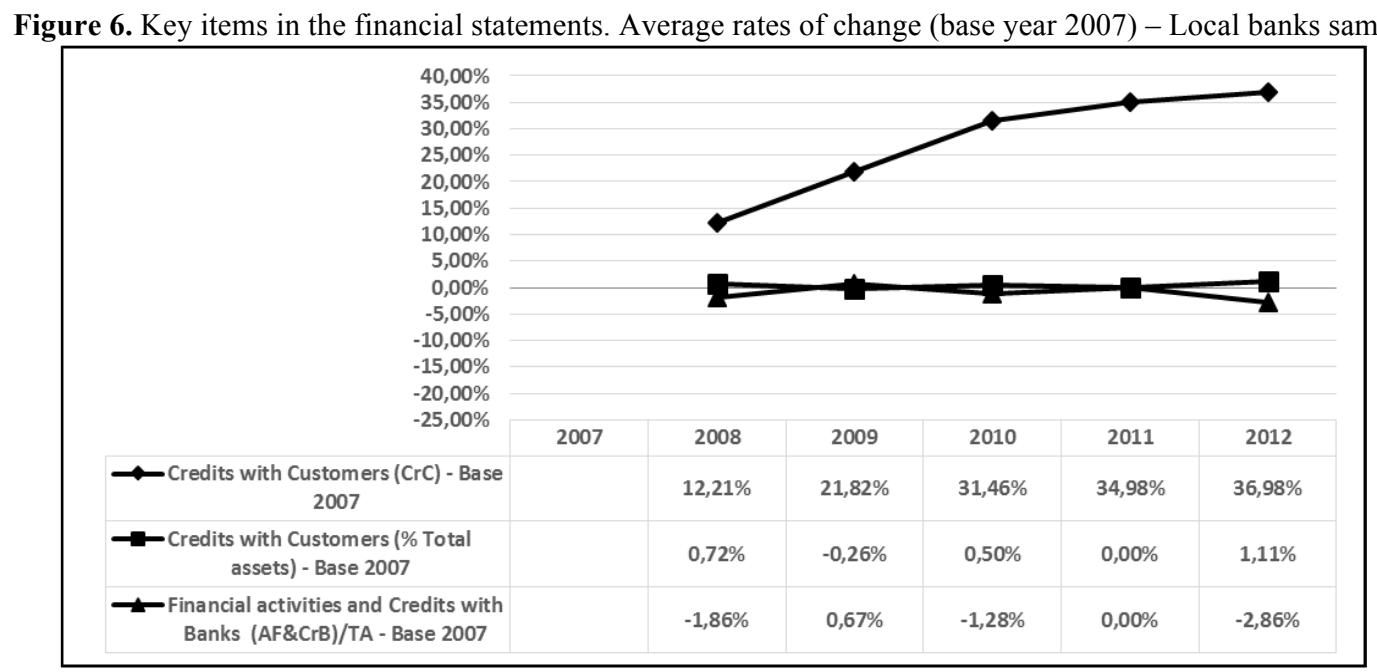

Source: Our elaboration Federcasse data.

The following graph (Figure 7) shows the annual trend of Total Assets (TA) and financial assets as well as bank loans to total assets ratio $(\mathrm{AF} \& \mathrm{CrB} \div \mathrm{TA})$.

Figure 7. The dynamics of total assets and financial activities (period 2007-2012) - Local banks sample (k€)

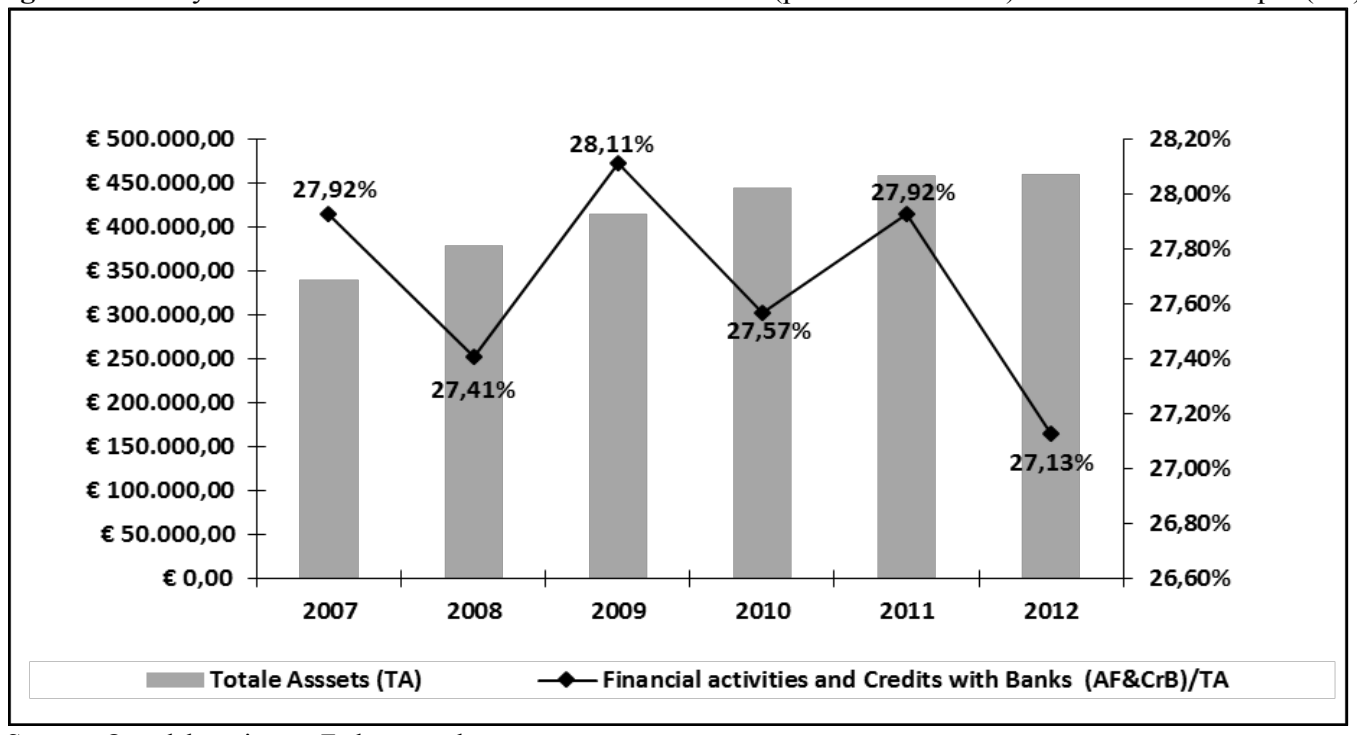

Source: Our elaboration on Federcasse data.

In other words, therefore, the local banks show a sort of "immunity" or "independence" with respect to the performance of the national credit consequent to the EBA recommendations. Core Tier 1 ratio of local banks sample (Figure 8) shows a significantly different trend compared to national banks; in fact, while the national banks sample 
records the progressive increase as early as 2008, reaching, in 2012, values in line with those required by the European Banking Authority $(9.10 \%)$, the BCC sample shows the trend deterioration.

Figure 8. Core Tier 1 ratio - Local banks sample

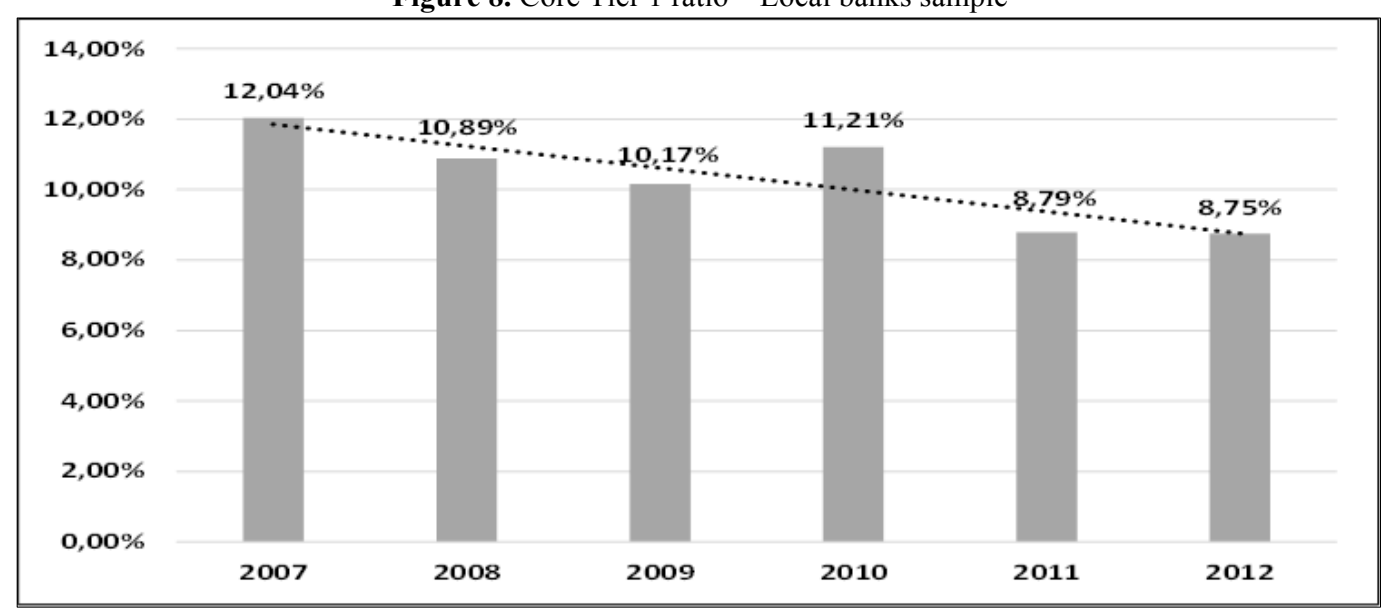

Source: Our elaboration on Federcasse data.

\subsection{Comparison Between National and Local Banks}

As previously mentioned, unlike the local banks, it is evident for national banks the strict dependence of lending activities by capital requirements (EBA effect). In this side financial statement data are processed not as absolute values, but as rates of change compared with 2007 (Taken as the base year). With reference to the performance of the first magnitude of the balance sheet analyzed, that is the "Credits with customers", there are some differences between BCCs and bank groups.

During the reporting period (2007-2012) "due from customers" reveal to be growing only in the categories of local banks investigated.

The BCC, in addition to recording in 2012 an average annual growth rate of Credit to Customers of $36.98 \%$ (base year 2007), sees the systematic and increasing trend of annual rates of change. Banking groups instead are characterized by the dynamics of decreasing credit (-13.66\% to 2012). Overall, therefore, local banks consolidate and strengthen their competitive positions and show a good dynamism of core business. This first empirical evidence confirms the following: 1) The immunity from EBA effect; 2) The presence of a direct relationship between bank's size and dynamics of credit to customers; 3) The special preference for local banks to adopt business models that focus on characteristic credit intermediation services (management approach of the relationship lending) - Similar conclusions were also reached by Tutino, Colasimone \& Brugnoni (2012). With reference to the third point, it is useful to analyze the weight of credit intermediation services by calculating the ratio "Credit with Customers $\div$ Total Assets". The good dynamics of loans to customers has seen the BCCs recorded a growth index $(+1.11 \%$ to 2012 compared to $-16.85 \%$ recorded by the banking groups). The data, overall, confirmed what had already been highlighted above, i.e. the propensity of banks, suited to the territory, to focus and to lending activity. Strictly complementary to the analysis of the dynamics of loans is the examination of impaired exposures, represented prevalently from "non-performing loans" and "credit write-down".

The trend of non-performing loans from 2007 to 2012 indicates for banking groups a constant percentage increase, with the datum that grows systematically in the period under observation $(+156.12 \%$ to 2012 - base year 2007).

The dynamic of BCCs is worse, in fact it marks an average rate of change of $238.12 \%$ in the period $2007-2012$. 
These evidences underline how the lending process has been, generally, characterized by the significant deterioration in credit quality during the years of international crisis.

Despite the growth of "non-performing loans" joins the universe we surveyed, BCCs register the highest percentage values, above all starting from 2009 ( $+93.16 \%$ in $2007-2009$ compared to the delta $+31.89 \%$ for the period 2007 2008) when the crisis is reflected also on real economy.

As can be seen from the study of Arnone, Bechi \& Modina (2013): "The different dynamic compared to banking groups, in non-performing loans, must necessarily encourage local banks to diversify their offer models".

Empirical evidences on bank pains are also confirmed in relation to the performance of "value adjustments on credits" (Credit write-down). With reference to the analyzed period, banking groups recorded a decline in the parameter starting from 2010, while BCCs saw "Credit write-downs" grow systematically (compared to 2007: $+192.46 \%$ ).

In short, empirical analysis see local bank focused on core activities.

The analysis, "sic et simpliciter" of credit to customers trend, shows that a sort of immunity of BCCs by EBA effects. On the contrary, local banks have reported growth rates of non-performing loans and credit write-down higher than other banks. Consistently with the results of Minetti's (2013) analysis, Tutino, Colasimone \& Brugnoni (2012) and Quintiliani (2017) also our investigations, therefore, allow us to say that in the years of the crisis, local banks have continued to support the entrepreneurial, while remaining faithful both to their role as privileged partners of businesses and families in the territory and a business model based on credit intermediation.

Complementary to the analysis developed in the previous paragraph, here we try to grasp further evidence on structure, riskiness, profitability and efficiency of banks placed under observation.

Remaining in the analysis of the profile structure, the ratio under observation "Total collection $\div$ Total assets" expresses the incidence of debts with customers and debts represented by bonds, savings deposits, certificates of deposit, spot against forwards on total assets (Quintiliani, 2017).

As Quintiliani (2017) says, "This ratio provides a measure of onerous level debt supported by banks". Small banks recorded a stable growth of the parameter. Unlike large banks, the ratio is more intense until $2009(+6.71 \%$ in 2007 2009 compared to the delta $+0.11 \%$ recorded by the banking groups).

The recession and the sovereign debt crisis hampered the placement of bonds, while the growing competition in the market of credit intermediation caused the rise in interest rates on deposits.

As Quintiliani (2017) says, "The combined effect of these two factors, as it emerges from the dynamics of parameter, has influenced on the composition of the debts of banking groups, by imposing them the research of forms alternative to traditional funding; vice versa, local banks, pegged to traditional models of corporate lending, are characterized by the lack of poor financial flexibility and low propensity to develop more complex fundraising activities of those ones either to pursued".

Continuing to examine the structure profile, the second ratio "Due from customers $\div$ Direct deposits" expresses the intermediation ratio referred only to the operation exchanged with customers (Quintiliani, 2017). Respect to banking groups, BCCs show substantial and stable decline of the indicator (compared to 2007: -0.98\%); this decline is justified by the progressive increase in direct deposits as a channel privileged by small banks to obtain financial resources.

After a decline in the years immediately following the international crisis, banking groups see the index grow steadily ( $+2.98 \%$ to 2012 - base year 2007); this empirical evidence can be considered coherent with the hypothesis formulated in literature that sees large banks to take corporate banking models.

With reference to the analysis of the risk profile, the indicator used to catch the dynamics of credit risk in the credit cooperative system is delivered in terms of "Value adjustments on credit $\div$ Credits with customers". As a result of 
global crisis, the values of this indicator have decreased significantly for banking groups (2007-2008: -244.08\%; 20072012: -300.01\%) but increased, without knowing set backs, for small cooperative banks (2007-2008: +43.55\%; 2007 2012: $+117.89 \%)$. These dynamics confirms what emerged in the analysis of non-performing loans.

Despite the economic downturn, the cooperative credit system, no matter what the highest costs associated with deteriorating loan quality, has seen its banks adopt an intense credit allocation policy.

A similar phenomenon was detected by Baravelli, Feliciotto \& Mazzù (2002) for BCCs operating in Sicily (Italy).

These findings allow us to affirm that small banks, with operations traditionally anchored to lending activities, must necessarily revise their scoring models, in order to ensure better integration between hard and soft information (Del Prete, Pagnini, Rossi \& Vacca, 2013; Quintiliani, 2016).

As Quintiliani (2017) says, "The question of the information advantage of the person who is physically closer to the territory, than bank groups with notoriously centralized structures that rely on objective information (hard information) or per tabulas, requires to be better rationalized, coming out of a too simplistic representation. It's really true that hard and soft information requires a more balanced mix (having passed in the credit approval practices by the excesses of the mere personal knowledge of customers to those of impersonal knowledge) but the rhetoric of looking at the entrepreneur's eyes must be disproved as a means to establish its reliability as a credit counterpart. His history is important, but is not sufficient to assess the quality of the projects that he has in mind to realize and it cannot be a diriment element when no positive factors emerge from official documentation".

With reference to the analysis of the profitability profile, the first ratio being surveyed is "Net interest income $\div$ Net interest and other banking and insurance income". This ratio provides information on the scale of bank deleveraging.

Lower values of this ratio denotes the increased ability of the bank to generate income outside traditional lending activities (Quintiliani, 2017).

In comparison with 2007, average rates highlight some differences between the two categories of banks placed under observation, particularly interesting.

With reference to banking groups the ratio shows an increase until $2009(+1.58 \%$ compared to base year 2007) and then a decrease, but with low intensity in the following years (-0.45\% in $2007-2012$ period).

Change rates, rather marginal, indicate how banking groups, despite the difficult economic climate, have managed to achieve in the contest of production processes of income flows, a balanced mix between money management and management of the services.

The negative sign of the percentage changes recorded by the BCCs (2007-2008: +1.89\%; 2007-2009: -11.41\%; 2007 2010: $-10.21 \%$; 2007-2011: $-8.09 \%$; 2007-2012: $-12.67 \%$ ) indicates the tendency of local banks to extend their range of high value-added products and services.

The dynamics of the index leads us to reflect about the factors that can encourage or discourage local banks to develop less traditional business areas.

As Minnetti (2013) says, "If financial activity, favoured by the direct knowledge and continuity of relationship over time, is and will continue to represent the core business of local banks, there is the need for them to create an effective intervention space in offering innovative and complex services that is visible and recognized by the market".

Minetti's (2013) comments allow us to reflect on the obstacles which are preventing the local banks to start diversification and deleveraging processes: inadequate staff skills and a shortage of products/services to offer in addition to the traditional ones. 
Profitability analysis concludes with the dynamics of the second ratio: "Profit/loss for the year $\div$ Net assets"; this ratio indicates the return on equity (ROE) of the bank.

The crisis has caused a significant negative effect on the ROE of BCCs and banking groups.

Banking groups register a parameter contraction much more intense than BCCs $(-24.19 \%$ in $2007-2008 ;-25.60 \%$ during the 2007-2012 period).

For small cooperative banks, the contraction of return on equity begins to assume an alarming rate starting from 2009 $(-16.59 \%)$. In particular in 2010 the decrease is more than 30 percentage points; in 2011, the decrease was less pronounced (2011: $-16.27 \%$; 2012: $-16.38 \%)$.

These empirical evidences show how the unfavourable economic situation, outlined as a result of crisis, is worrying for all types of banks surveyed.

Whatever is the solution to adopt, there is no doubt that the shrinking of net interest income (lower profitability of lending activities) must be offset with the desirable increase in net interest and other banking and insurance income and in other net banking income.

With reference to the analysis of the "profile of efficiency", the ratio considered is the cost-income ratio that is "Operating expenses $\div$ Net interest and other banking and insurance income". Its reduction means that the incidence of costs, compared with the wealth produced, decreased so that the bank is more efficient (Quintiliani, 2017).

In the years immediately following the outbreak of the financial crisis (later real), banking groups recorded worse performance (annual growth rates up to $2008:+10.88 \%$ ) than BCCs (annual growth rates up to $2008:+8.36 \%$ ).

Starting from 2009, when the financial crisis becomes real, banking groups see the shrinking of the incidence of their operating expenses, while BCCs recorded a progressive growth of the parameter. To 2012 local banks show a positive percentage delta of $22.30 \%$ while national banks recorded a negative delta equal to $2.98 \%$.

The growth trend confirms the difficulty of BCCs to ensure optimal coverage of operating expenses thanks to income flows coming from trading and hedging activities (Net interest and other banking and insurance income and other net banking income); also, this empirical evidence shows how the business models of local banks, as primarily focused on traditional corporate lending and less oriented to corporate banking, underweight the offer of services with higher added value (Quintiliani, 2017).

\section{CONCLUSIONS}

Referring to R.Q.1, the main emerging evidence from the empirical analysis show an increase in financial activities and a significant reduction in the volume of loans to customers. In general, it appears that the reduction of the risk profile of the financial statement's assets and, consequently, the improvement in the Core Tier 1. In terms of EBA effect, national banks do not seem to be immune; in fact, the dynamic of lending highlights constraints in relation to additional capital requirements. In particular, it found the immunity of BCCs by the EBA; these, in the crisis years, have largely retained, if not slightly increased, their competitive position in the credit market.

The empirical analysis proposed here, in line with the literature, has confirmed that local banks in the years of the crisis have increased their competitive position in the credit market.

Overall, the world of the cooperative banks is a vital one and able to support the financial needs of local areas.

Cooperative Credit Banks (BCCs) or mutual banks are strategic players in the Italian banking system. The deep knowledge of the territory and the ability to assess business projects contributed, over time, to make local banks important interlocutors for SMEs. 
The tensions that characterized the financial sector in recent years and the recession phase, which is still developing, see local banks face challenges no less difficult than those faced by the rest of the banking system. However, the findings have shown some critical issues in contrast to the advantages described in the literature (see the second paragraph) and which are negatively reflected on risk-return profile of local banks; these critical elements are summarized below: i) An increase in non-performing loans (progressive deterioration of loan portfolio); ii) A loan portfolio inadequate to optimise risk profile; iii) Low financial flexibility and low propensity to develop collection strategies more complex than those pursued; iv) Rating models unable to combine hard and soft information; v) Poor product/service range alternative to traditional ones; vi) Poor skills and resources to start business diversification processes.

In order to answer the R.Q.2, the proposals for improvements, in favour of Cooperative Credit Banks emerging from this work areas (Quintiliani, 2017): i) The expansion in the range of services; ii) Innovation in evaluation of creditworthiness assessment; iii) Investment in training and appropriate professional recruitment to diversify business areas; iv) Development of new organizational models (network building).

If small local banks want to get rid of the growing competition that seeks to favor banking groups, they will need to initiate business diversification processes without giving up on the relationship with the clientele.

After all these considerations above exposed I wish point out that, in a context of crisis, local banks must necessarily play a role in different fields but closely related to the logic of continuing to be a solid reference point and capable for the companies they continuously operate.

As Minnetti (2013) stated, "If, in fact, the lending has always been the fundamental reason for the existence of local banks, it is clear that it can be no longer the only funding for firms, especially for the dynamics ones and with potential development. Equity resources, share and bond issues on markets, structured financing operations are some of alternative funding formulas that firms could require to which the financial intermediary system, in its different components, must respond with the preparation of a package of solutions and tailored products/services."

In the same direction, says Quintiliani (2017), will move new financing instruments for SMEs (Mini-bonds, Commercial Papers, Project Bonds), activated with the "Decreto Sviluppo" (Legislative Decree n. 83/2012) and "Decreto Destinazione Italia" (Legislative Decree n. 145/2013). The original aim of the lawmaker was to diversify the fundig sources of the SMEs in order to reduce the "credit crunch" phenomenon and excessive bancocentrism. The author adds: "It is clear that small banks have objective limits (cultural, skill and equity limitations) in order to start immediately business lines reentering in corporate banking, that can count on significant income flows. But, on the other hand, they cannot remain passive and motionless in front of demands of change coming from their main customer, that is the world of SMEs. In this sense, local banks must necessarily create shared tracks with other banks that are in the same situation by speeding up system initiatives and at the level of association to which they belong or to fix relationship of collaboration and/or partnership with specialized institutions".

Appear significant margins for the realization of durable efficiency recoveries, taking full advantage of the benefits of the network and the support offered by the federal structures (Tarantola, 2011). The resources thus released could support a process of development, such as through the expansion of services offered to customers, including new ways of managing the relationship with the retail market enabling to rethink and rationalize the role of the physical network on the territory. The evolution of banking services must be accompanied by unavoidable investments on organizational and technological interventions needed to fully grasp the opportunities that already the reform of Basel 2 and Basel 3 offered asks, in fact, not to defer further: the continuous improvement of evaluation techniques, selection, pricing and the exploitation of credit risk mitigation techniques are among these. It is very strong, also, the need to promote the integration of information bases used and support with more advanced tools for analysis and reporting on the strategic planning process. It is also a key step.

While "networking", outsourcing and centralization are the key words of a strategy aimed at improving management, efficiency, will on the other hand the ability to "think strategically" which will have to drive virtuous evolution of the cooperative credit bank's business model. It will thus combine the competitive advantage of the relationship lending with the renewal of processes, products and ways of interacting with customers. Only in this way, the defense of the 
ancient peculiarities of the movement, of the selective ability that they have been strong point, will be functional to the creation of an offer able to provide the necessary support to the real economy.

In this direction tends, also, the recent reform of the cooperative credit (Legislative Decree n. 18/2016); in the general context of the banking industry, Cooperative Credit Banks, despite the competition, should create a system and the reform is a mode in which this system is realized and efficient.

The reform is essentially based on the integration of the mutual banks in a "cooperative banking group" (limited company).

Within the cooperative banking group, it is safeguarded the principle of autonomy of the individual BCCs that will continue to have individual banking license and autonomy in electing their own representatives; at the same time the cooperative banking group will exercise coordination on BCCs.

The reform stems from the perception of European regulators of some elements of weakness of BCCs than the requirements imposed by the new prudential regulations: i) The operating model, focused on typical retail business and therefore particularly sensitive to changes in the real economy in the areas of reference; ii) The average small size of BCCs and their large number with effects on costs and investment/innovation capacity; iii) The total organizational structures in the system.

Essentially, the era banking union, the single mutual bank does not seem to have survival prospects in atomistic form, because: i) The difficulty for immediate reaction to capitalization requirements; ii) The size; iii) The increasing costs of organizational and administrative nature.

The European institutions then asked to respond to higher loads (in terms of competitiveness, profitability, stability of the system, strengthening capital adequacy of individual banks) integrating individual BCCs: this intuition of the reform in a cooperative banking group (legal entity wholly original and innovative in the Italian and European legislation).

\section{AUTHOR BIOGRAPHY}

Andrea Quintiliani, Ph.D. - Associate editor for JABR (Journal of Applied Business Research), I am currently Assistant Professor in the scientific field "Economics and Business Management" at the Pegaso Telematic University, where he holds courses in "Corporate Finance" and "Business Economics and Management".

The research activity, carried out both on a personal basis and as a member of research groups, has developed in the following areas: a) Banking and finance; b) Intangible value; c) Internal rating banking; d) Corporate value; e) SMEs; f) The value creation in manufacturing and financial companies Basel 3, the effects on bank-firm relationship and the role of corporate finance; g) The management of the investment and financing techniques with a focus on the relationship between banks and firms, particularly small and medium-sized (SMEs), especially in light of the introduction of new assessment models credit (i.e. internal rating systems); h) The quality of financial and banking services for SMEs.

\section{REFERENCES}

Allen, F.E., Carletti, E. \& Gale, D. (2008). Interbank Market Liquidity and Central Bank intervention. Working Paper, University of Pennsylvania.

Arnone, M., Bechi, A. \& Modina, M. (2013). Financial crisis, private equity and technological districts: opportunities and challenges for local banks. Quarto Workshop Internazionale sulla Finanza Cooperativa EURICSE, 19-21 Giugno, Trento.

Baravelli, M., Feliciotto, P. \& Mazzù, S. (2002). Strategie e organizzazione della banca. Milano: Egea.

Berger, A.N. \& Udell, G. (2006). A more complete conceptual framework for financing of small and medium enterprises, Journal of Banking and Finance forthcoming.

Berger, A.N. \&, Udell, G. (2002). Small business credit availability and relationship lending: The importance of bank organisational structure. Economic Journal, 112, 32-53. 
Berger, A.N., Miller, N.H., Petersen, M.A., Rajan, R.G. \& Stein, J.C. (2005). Does function follow or-ganizational form? Evidence from the lending practices of large and small banks. Journal of Financial Economics, 76, 237-269.

Berlin, M. \& Mester, L.J. (1998). On the profitability and costs of relationship lending. Journal of Banking and Finance, 22, 873897.

Bernanke, B.S. \& Lown, C.S. (1991). The Credit Crunch. Brookings Papers on Economic Activity, 205-239.

Boot, A.W.A. (2000). Relationship banking: What do we know?. Journal of Financial Intermediation, 9, 7-25.

Corigliano, R. (2007). Banca e impresa in Italia: caratteri evolutivi del relationship lending e sostegno dello sviluppo. Banca Impresa Società, 1, 27-58.

De Laurentis, G. (2011). Business credit after the crisis. Roma: Bancaria Editrice.

Degryse, H. \& Van Cayseele, P. (2000). Relationship lending within a bank-based system: Evidence from European small business data. Journal of Financial Intermediation, 9(1), 90-109.

Del Prete, S., Pagnini, M., Rossi, P. \& Vacca, V. (2013). Organizzarsi per prestare in tempo di crisi. Risultati di un'indagine sulle banche. Questioni di economia e finanza, Banca d'Italia, 154.

Diamond, D. (1991). Monitoring and reputation: The choice between bank loans and directly placed debt. Journal of Political Economy, 99, 688-721.

Domaç, I. \& Ferri, G. (1998). The Real Impact of Financial Shocks: Evidence from Korea, World Bank. Policy Research Working Paper, 2010, Washington, DC.

European Banking Authority - EBA (2012). Recommendation on the creation of temporary capital buffers to restore market confidence.

Fama, E. (1985). What's different about banks?. Journal of Monetary Economics, 15, 29-36.

Ferri, G. \& Messori, M. (2000). Bank-firm relationships and allocative efficiency in northeastern and central italy and in the south. Journal of Banking \& Finance, 24(6), 1067-1095.

Jayaratne, J. \& Wolken, J. (1999). How important are small banks to small business lending? New evidence from a survey of small Firms. Journal of Banking \& Finance, 23, 427-458.

Minnetti, F. (2013). Banche locali e PMI nel mercato del credito: dalla crisi un forte impulso per rivedere la relazione in chiave evoluzionistica". LUISS CASMEF, Working Papers, 8, Dicembre.

Petersen, M. \& Rajan, R. (1995). The effect of credit market competition on lending relationships. Quarterly Journal of Economics, 2(110), 407-443.

Quintiliani, A. (2016). Internal rating systems e soft information. Il ruolo degli intangibili e del contesto territoriale nella valutazione del merito creditizio delle PMI. Milano: Franco Angeli.

Quintiliani, A. (2017). Financial Crisis and Local Banks: a Review of Bank-Firm Relationships in Italy. Corporate Ownership \& Control, 14(3-1), 249-258.

Quintiliani, A., Modina, M. \& Arnone, M. (2013). Il ruolo delle banche locali e del relationship lending in scenari economici in profondo cambiamento. Arethuse Rivista di studi economico-gestionali, 2/2, Società Editrice Esculapio, Bologna, 91106.

Rajan, R.G. (1992). Insiders and Outsiders: The Choice between Informed and Arm's-Length Debt. The Journal of Finance, 47(4), 1367-1400.

Stiglitz, J.E. \& Weiss, A. (1981). Credit Rationing in Markets with Incomplete Information. American Economic Review, 71, 393-409.

Tarantola, A.M. (2011). Il Credito Cooperativo del domani: sviluppo, efficienza e solidarietà. Intervento del Vice Direttore Generale della Banca d'Italia al XIV Congresso Nazionale del Credito Cooperativo, 9 dicembre.

Tutino, F., Colasimone, C. \& Brugnoni, G.C. (2012). Il credito alla clientela in Italia e la recente crisi finanziaria: andamento, qualità e modello di intermediazione. Evidenze empiriche per dimensione di banca. Banca Impresa e Società, 31(3), 365-399.

Yosha, O. (1995). Information disclosure costs and the choice of financing source. Journal of Financial Intermediation, 4(1), 320. 